\title{
Analysis of Green Marketing Tools towards Consumer Purchase Intention in Kathmandu
}

\author{
Shulov Shrestha ${ }^{6}$
}

\begin{abstract}
The main purpose of this study is to examine the impact of green marketing tools on product choice and how green initiatives influence purchase intention of consumers. The research also attempts to examine the relationship between age, income, education, and occupation with consumer purchase intention in association with green marketing tools. The study is descriptive in nature and focuses on hypothesis testing using structured questionnaire and interview. Structured questionnaire is used to collect primary data from a sample size of 120 respondents focusing on employed, self-employed, students and homemakers. These groups are assumed to represent green purchase in today's society. However, opinions of marketing professionals have also been considered. The survey population represents the people who go for shopping; data have also been collected from the point of purchase. Green purchase intention was seen to be incremental considering the increase in the level of education of individuals. Green marketing tools i.e., environmental belief, green packaging, green branding, green advertisement, green labelling has been taken into account to observe its significance towards consumer purchase intention. Likert scale questions with five-scalerating were used to do the hypothesis testing. The questions included statements in conjunction with the measure of green marketing tool's influence over consumer purchase intention. The research revealed that green marketing tools played a significant role in inducing a positive purchase intention towards green products. While there exists growing preference towards green products, price plays a major role in product purchase.
\end{abstract}

Key Words: Eco-brand, Green product, Environmental responsibility

6 Mr. Shulov Shrestha is involved as HR Officer at Rosebay Consulting Pvt. Ltd. Kathmandu, Nepal

Corresponding email:shulovshrestha@gmail.com 


\section{Introduction}

Green Marketing is the marketing of products and services that are recognized to be environmentally safe. It incorporates product/service modification, making changes in production/packaging process and advertising. Green marketing involves establishing a link between the business and customer by carefully integrating social and environmental concerns. In contrast to Traditional marketing which involves outbound marketing (television advertising, print advertising, direct mail and telemarketing), and focuses on push strategies, green marketing uses inbound marketing, which focuses on pull strategy. This process entails holistic approach since business naturally has to integrate all the activities in line with environmental concerns. As a strategy, green marketing involves strategic options such as green products, green packaging, green prices and green communication (Ottman, 1998). The growth of green marketing and green consumer is, "perhaps the biggest opportunity for enterprise and invention the industrial world has ever seen" (Cairncross, 2003).

Consumers from the developed countries, including USA and Western Europe, were found to be more conscious about the environment (Curlo, 1999). The industry for green products was estimated at over \$200 billion in 2006 (Gupta and Ogden, 2009). The overall market for green marketing is believed to be worth $\$ 3.5$ trillion by 2017, according to a report by Global Industry Analysts Inc. of 2011(Aryal, 2008).

The demand for organic products has also increased during recent times, especially in Kathmandu, Chitwan and Pokhara cities of Nepal. The number of market outlets for organic products has increased in Kathmandu. Traders have reported that consumers are willing to pay premium price (Aryal et. al., 2009) for such products. Market features of organic products in Nepal show that it is still in the "formative stage" of the product life cycle (Bhatta et al., 2008).

There has been an increasing debate about environmental issues focused on sustainable living and environmental preservation all over the world. Today, aware consumers are concerned about how their purchasing habits can help to minimize negative impact on environment. These serious changes have stimulated business houses and production companies to be more socially and environmentally responsible by creating positive or minimizing negative impact on society and environment caused by production of products and services. The production of green products is a challenge to all businesses, as requirement of quality, cost, performance and environmental issues needs to be met. Though the concept of green marketing has been quite successful in the developed countries, its impact is 
yet to be seen in Nepal. This paper identifies that greater cost of green products is a big constrain towards consumers opting for greener option in Kathmandu.

Going green is becoming more than just a trend in Nepal; it has been seen as a means to gain sustainable growth. There has been emergence of eco fairs and initiatives supported by profit and not for profit organizations operating in service and manufacturing industries. For example, Laxmi Bank installed solar lights in Bagmati Bridge, the Green Angel project has created green jobs for rural and young Nepali women helping them in a self-sustained business of making, and distributing cloth and paper shopping bags to replace use of polythene bags in Kathmandu, Dabur Nepal and other companies have initiated on eco packaging. Though these green initiatives have had their share of benefits for companies, the impact of these initiatives are not fully known. It is also difficult to truly know the significant impact of these initiatives towards improving brand image and gaining customer preference. Therefore, studying the behaviour and perception of consumers towards green purchase would not only benefit marketers but also help understand the underlying reasons facilitating green product adaptation. It would also be an insight to governments and societies to create a more sustainable and eco-friendly environment by facilitating to reduce the right pain points to increase adoption of eco-friendly products and services.

The developments observed in Nepal portray efforts of the government, organizations and intention of consumers towards creating a sustainable environment by promoting organic products and environmentally friendly behaviour. Green marketing tools such as eco packaging, green branding, green advertising, green labelling and environmental belief have been the major guiding attributes towards identifying purchase intention in this study. Hence, this study would primarily benefit businesses, investors and marketers. Studies conducted in Nepal (Aryal et. al., 2009, Bhatta et al., 2008, Aryal, 2008) focus primarily on the organic product market; however this study tries to give a comprehensive picture of the Nepalese urban consumer product preference and acknowledgement towards green marketing initiatives. However, these studies are limited to consumers living in Kathmandu and post purchase behavior of consumers still remains to be studied.

\section{Literature Review}

Handrina (2016) made a study to identify perception of public towards green purchase in Indonesia. The research studies perception of groups of professionals, young people and housewives as these groups are assumed to contribute largely towards green buying. In-depth, interview was done to collect data in order to meet research objectives. It was found that green behavior differs amongst people. Young people (students) were found to be more inclined to behave green. Concern 
for health and environment acts as a catalyst for this inclination towards green products, however higher price of such products becomes a pain point. Similarly, Rahbar \& Wahid (2011, Malaysia), Shen (2012, China), Aryal, Chaudhary, Pandit \& Sharma (2009, Nepal), Bukhari (2011, India) have contributed in the similar type of research outcome further revealing that consumers are inclined towards purchasing products that they are emotionally attached to and are willing to pay a higher price.

Isa \& Yao (2013) conducted a study to investigate consumer preference for green packaging in consumer's product choices by using choice based conjoint approach. They also studied the extent to which the price sensitivity, attitude towards brand, convenience of use of the packaging, green packaging label, and product design influence on customer purchase intention based on real product choices. A choice based conjoint analysis was applied in the first part and a personally administered questionnaire was distributed to $180 \mathrm{Tesco}$ (International grocery and retail outlet in Malaysia) consumers in the second phase of the study. It was found that price was the leading factor of consideration; however, consumers were also attracted by product label while making green purchase. Green packaging or ethical product aspects were found to have no significant influence on consumer product choice. On the contrary, it was found that price was not significantly influential, whereas product label and design were found to demonstrate positive and significant influence in consumer product choices. Similarly, Deliya\&Parmar (2012), did a study on the topic "Role of packaging on consumer buying behavior- Patan District". The research highlights how appropriate and vivid picture or packaging color delivers a happy feeling among consumers, or an easy handle/open/close/ dispose package shape are important in catching a customer's attention leading to purchase decision. It reveals that elements of package are one of the most important attributes for consumer purchase decision.

Borin, Cerf \& Krishnan (2011) conducted a study aimed to investigate the impact of different levels of environmental information in key consumer metrics and to evaluate environmentally benign products against those that have negative environmental impacts. Multiple product categories and messages that varied from strongly negative to strongly positive were used to test whether the accuracy/completeness of the information changes consumer's view of green products. It was found that consumer perception of product quality, value and purchase intentions do not differ significantly between products with positive environmental messages and those without any message. Products with positive environmental messages are viewed better than products with negative environmental messages. It is also found that the impact of environmental information is greater for consumable products. It shows that clearly presented 
information can make a significant difference in the process of consumer product evaluation. Likewise, D’Souza, Taghian\& Lamb (2006) conducted a similar study to examine influence of environmental labels on consumers. It was found that sizeable number of consumers found it hard to understand the product. There were consumers who buy green products even if they are low in quality in comparison to alternative products, but would look for environmental information on labels.

Richards (2013) identified the impact of green advertising through evaluating consumer's connection to the environment and the factors that indicate the trust in advertising and willingness to purchase green products. A sample of 107 students was taken from students and faculty of Elon University and data collected through a questionnaire. The participant sample covered a wide range of demographics and environmental activism in order to explore the correlation between enthusiasts and green purchasing patterns. The research method was designed to allow participants to openly share their opinions of green advertising and the "green washing" trend. The results showed that there is evidence linking environmental enthusiasm with consumer scepticism of both general and green advertising. It indicated that environmental enthusiasts are often more sceptical of both forms of advertising, with non-enthusiasts remaining more neutral. Consumers value green products and brands that are trustworthy, affordable, healthy and environmentally beneficial. Likewise, Niazi et al., (2012), Saleem\&Abideen (2011), conducted a similar research. These researches revealed that positive relationship between emotional response, attitudinal response and consumer buying behavior resulted in the purchase of those products that the consumers are emotionally attached to.

Mourad \& Ahmed (2012) researched to study the main factors affecting the green brand preference in the telecom industry in Egypt. A four-dimension construct of green brand preference was developed: green brand image, green satisfaction, green trust, and green awareness. A qualitative exploratory research was conducted followed by a quantitative research in the form of a survey distributed among 302 respondents. It was found that consumers tend to disagree that they are aware of environmental promotions or that they recognize the meaning of environmental slogans and labels for their preferred brand. The correlation between green awareness and green brand preference was the weakest. On the other hand, there was a strong correlation and positive effect of the other factors (green brand image, green awareness and green trust) and green brand preference. The effect of the factors on green brand preference was not significantly different for different genders, while it was significantly different for ages, income levels and education levels. Also, Chatterjee (2009) also did a similar study where Brand extension evaluation, purchase intent, and parent brand evaluation were measured. The study concluded that consumers are more likely to purchase green extensions of products 
with high perceived environmental impact and that current consumers prefer green line extensions to green category extensions.

\section{The Methodology}

\subsection{The Basic Model}

Consumer purchase intention is a process by which an individual plans future purchase of goods and services. It is a sum total of a consumer's attitude, preference, and decision regarding consumer's behavior in the marketplace. Whitlark, Geurts and Swenson (1993) define purchase intention as a purchase probability associated with an intention category at the percentage of individuals that will actually buy product. This study analyzes the effect on purchase intention of consumer considering the use of green marketing tools. A comprehensive model was developed on the premise of research paper presented by Juwaheer, Pudaruth\&Noyaux (2012), "Analyzing the impact of green marketing strategies on consumer purchasing patterns in Mauritius". The model shows green marketing as independent variable, which influences the consumer's intention to purchase. Other factors such as age, occupation, gender, price, income and education act as moderating variable.

Independent Variable

Dependent Variable

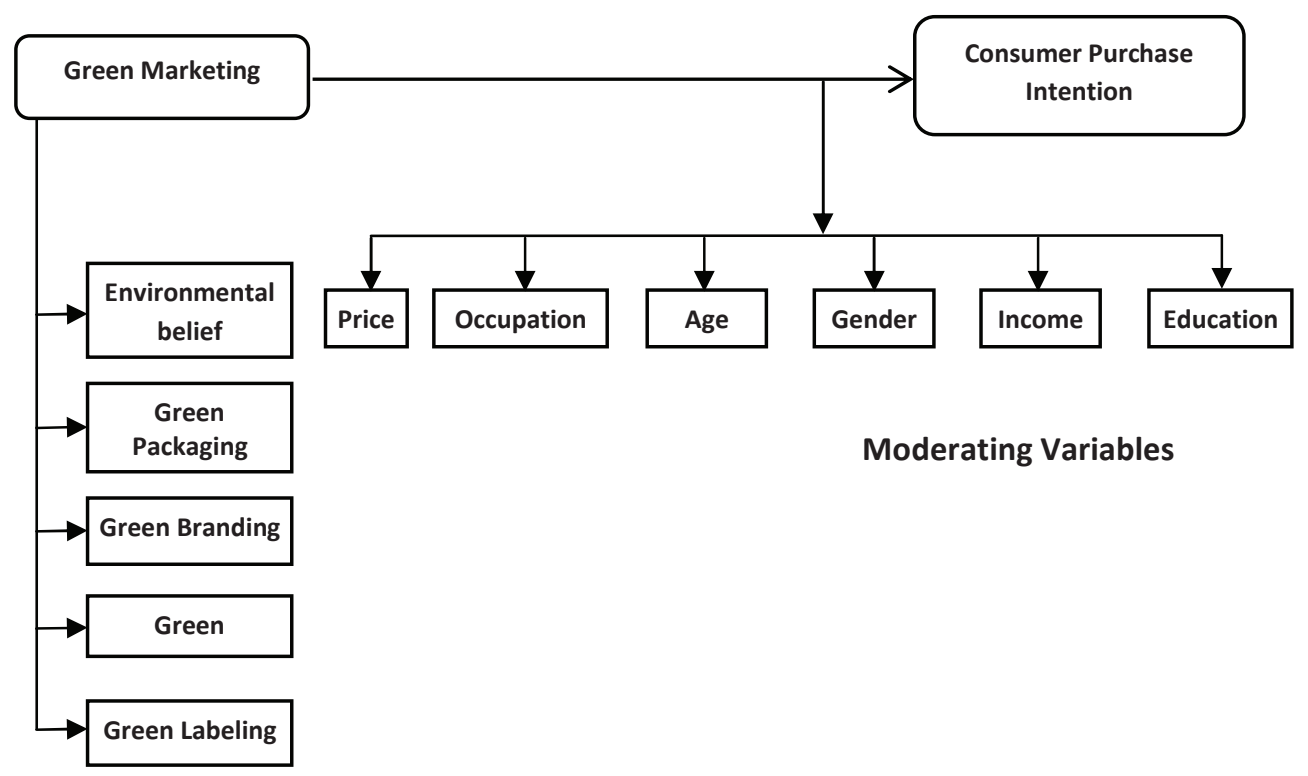

Fig. 1 Conceptual framework of the study 
Environmental Belief: The environmental belief refers to convictions that are held to be true by individuals or groups regarding concepts, events or things. International researchers show that the consumers worry more about the environment and gradually change their behavior (Arbuthnot, 1977; Simon, 1992). Furthermore, consumers' values and beliefs need to be thought about when exploring the influences affecting purchase decisions (Hoyer and MacInnis, 2004). Theory of planned behavior proposed by Ajzen's (1991) demonstrates that environmental beliefs shape attitude towards behavior, which in turn is translated into buying intention. ( Hoyer \& Deborah J. MacInnis, 2004)

Green Packaging: It is an approach towards product packaging that considers full environmental impact of the production and disposal of the packaging material. A sustainable package will generate less waste than conventional packaging and will be manufactured from materials that use as much recyclables material as possible using least amount of energy.

The concept of being environmentally friendly or green will have an effect on all parts of business from the conception of products to the use of subsequent disposal of the product by customers (Prahalad\& Hamel, 1994). Packaging can be considered ecological depending on the degree of environment pollution (Delia, 2010).

Eco-Labeling: Eco labels are symbols or marks given to a product on compliance to eco-friendly criteria laid down by government, association or standard certification bodies. Morris et al. (1995) have stated that specific product claims on product labels like "eco-friendly", "recyclable", "biodegradable" and "ozone friendly" used by marketers enabled companies to communicate the environmental benefits of products to their consumers.

Green Branding: Green brands are those that people can associate with environmental conversation and ecological/sustainable business practices. Several studies demonstrate that growing environment awareness of consumers have encouraged them to be more inclined towards brands that seemed to be environmental friendly (Eagly and Kulesa, 1997). According to Pickett et al., (1995), if green brand attributed are not well communicated, environmentally sustainable products will not be commercially successful. Similarly, other researchers have suggested that green positioning is an important element in the success of green branding strategies (Coddington, 1993; Meffert\&Kirchgrorg, 1993).

Green Advertising: It refers to a form of communication that highlights the environment friendly aspect of the product or organization. It involves promotional activities centered on environmental aspects. The objective of green advertisements 
is to influence consumer's purchase behavior by encouraging them to buy products that do not harm the environment and to direct their attention to the positive consequences of their purchase behavior, for themselves as well as the environment (Rahbar\& Wahid, 2011). Environmental advertisements help to form consumer values and translate these values into the purchase of green products (Baldwin, 1993).

In Nepalese context, majority of the studies have focused on the consumer buying behavior of organic and agricultural products. It is against this backdrop that this study aims to fulfil a gap by studying marketing element's impact on purchase intention of green products in Kathmandu on available green products categories.

This study aims to work on the following hypothesis:

Ho1: Environmental belief has no significant relationship towards consumer purchase intention.

Ho2: There is no significant relationship between green labeling and consumer purchase intention.

Ho3: There is no significant relationship between green branding and perceived brand image.

Ho4: There is no significant relationship between green advertisement and consumer buying behavior in Kathmandu.

Ho5: There is no significant relationship between eco packaging and consumer purchase intention.

\subsection{The Data}

\subsubsection{Population and Sample Size Determination}

A sample size of $120(58 \mathrm{M}, 62 \mathrm{~F})$ respondents was taken, to represent the population of Kathmandu. The sample size was decided based on the time and cost factor required to complete the research. The targeted population of the study consists of customers is above 18 years, living in Kathmandu. Consumers above this age are assumed to be active shoppers and also independently chose their products as observed while collecting data from consumers. The data was collected between September-October2015.

The target population represents people who are employed, pursuing higher education, and homemakers as they represent the largest demographics in Kathmandu. This study used the non-probability sampling technique. Under this technique convenience sampling is used to minimize the complexity. Therefore, 
this study uses convenience-sampling technique covering different locations in Kathmandu.

\subsubsection{Data Collection Procedure}

A structured questionnaire was designed and distributed amongst the people who reside in Kathmandu. The questionnaire includes demographic, single choice and a majority of likert scale questions with 5 scales $(1=$ strongly agree, $5=$ strongly disagree). The questionnaire measured perceived impact of environmental belief, eco packaging, green branding, green advertisement, green labeling towards consumer's purchase intention. Besides this, interview was conducted with various marketing personals.

The data collection was done online, using Google docs. Data was also collected from point of purchase. Besides the questionnaire, face-to-face and telephonic interviews were taken with the marketing managers and sales persons of different companies involved in green products, in order to truly realize the objective and the essence of marketing implication on the consumption pattern of green products. Respondents were selected primarily on the basis of their occupation, education and income level. This process of respondent selection captures real customers (independent decision makers) who make purchases at an individual and household level.

\subsubsection{Data Analysis Methods}

The data accumulated from the primary source was subject to various statistical tools for verification and interpretations. SPSS was primarily used for data analysis. Data analysis was categorized as: Descriptive and Inferential analysis. In order to present the understanding of data analysis, the results from the SPSS was copied to an Excel Worksheet, where it was refined and interpreted. Also necessary graphs, table and charts were derived using Microsoft Excel. For descriptive analysis: cross tabulation and mean analysis was done. In case of inferential analysis: Chi Square, t-test and ANOVA were carried out to draw the inferences from the collected responses.

Correlation was used to understand the relationship amongst variables representing green marketing elements. Correlation amongst the variables representing these green marketing elements help to determine the level of sync these variables have amongst themselves for better analysis of the hypothesis. 


\section{Results and Discussion}

\subsection{General Profile of Respondents}

The respondents represent people who are employed, pursuing higher education and homemakers as they represent the largest demographics in Kathmandu. The general profile of respondents is mentioned in the table below:

Table 1: Summary of Demographic variables

\begin{tabular}{|c|c|c|}
\hline \multicolumn{2}{|c|}{ Demographic Variable } & \multirow{2}{*}{$\begin{array}{c}\text { Percentage } \\
48 \%\end{array}$} \\
\hline Gender & Male & \\
\hline & Female & $52 \%$ \\
\hline \multicolumn{2}{|l|}{ Total } & $100 \%$ \\
\hline \multirow[t]{4}{*}{ Occupation } & Employed & $37 \%$ \\
\hline & Self-Employed & $13 \%$ \\
\hline & Student & $33 \%$ \\
\hline & Homemaker & $17 \%$ \\
\hline \multicolumn{2}{|l|}{ Total } & $100 \%$ \\
\hline \multirow[t]{5}{*}{ Age Group } & $18-25$ & $39 \%$ \\
\hline & $26-33$ & $36 \%$ \\
\hline & $34-41$ & $15 \%$ \\
\hline & $>41$ & $10 \%$ \\
\hline & Total & $100 \%$ \\
\hline \multirow[t]{4}{*}{ Income level } & $0-12,000$ & $44 \%$ \\
\hline & $12,001-25,000$ & $26 \%$ \\
\hline & $25,001-40,000$ & $18 \%$ \\
\hline & $>40,000$ & $12 \%$ \\
\hline \multicolumn{2}{|l|}{ Total } & $100 \%$ \\
\hline
\end{tabular}

\subsection{Descriptive Statistics}

The study shows that people were more enthusiastic about green products and attracted towards green products. Their perception of contributing towards environmental sustainability directed their willingness to spend a little more on green products. Marketing element such as product type, package, availability and product visibility were found to be equally important to influence consumer choice. Despite many available green product categories, food products were the most preferred green category of purchase.

Environmental belief was found to be a major source of positive reinforcement encouraging consumers to purchase green products (mean=1.88).Packaging not only attracted people towards green products but also helped consumers distinguish it from regular products (mean=2.14). Majority of respondents found green 
branded products reliable which shows positive influence of green branding $(m e a n=2.51)$. Advertisements also helped to spread green values and were accepted as a source of positive sway towards greener purchase intention $($ mean=1.9). Green label was observed to be an important tool to influence green purchase intention of consumers (mean=2.48).

The research revealed that male population was more enthusiastic about green products than female population. It was also seen that middle age individuals (3441 ) were the least enthusiastic about green products. While majority of respondents were insignificant about their purchase being eco-friendly, self-employed individuals were found to be more concerned about their purchase choice. The shortcoming could be because of the lack in belief that green brands are actually green. Despite this slight downside, both male and female across all occupation respondents were found to be attracted to purchase products that add to environmental values. Education is also seen to have a major influence on product perception and attraction. The aspect of environmental inclination amongst individual was seen increasing with higher level of education i.e. graduate level individuals were more attracted towards green products than individuals with undergraduate level education. They were also willing to pay more for green products.

It was seen that packaging was seen to make a huge difference towards structuring and enhancing purchase intention. Use of natural packaging materials projects the product as carrying green properties and also helps customers distinguish the product. However, majority of the population was only willing to pay a little more than what they were paying for a similar product.

\subsection{Reliability Testing}

To determine the reliability of statements grouped to test the hypothesis, correlation analysis was done amongst the statement in each group. All statements showed significant correlation amongst each other in their respective groups. 
Table 2: Correlation amongst factors influencing environmental belief

\begin{tabular}{|c|c|c|c|c|}
\hline Statements & $\begin{array}{l}\text { The } \\
\text { environment } \\
\text { is being } \\
\text { severely } \\
\text { damaged. }\end{array}$ & $\begin{array}{l}\text { I as a } \\
\text { consumer } \\
\text { have a bigger } \\
\text { role in } \\
\text { protecting } \\
\text { environment. }\end{array}$ & $\begin{array}{l}\text { Green } \\
\text { products are } \\
\text { better option } \\
\text { for future } \\
\text { sustainability }\end{array}$ & $\begin{array}{l}\text { If green features } \\
\text { increase the price } \\
\text { of a product, are } \\
\text { you willing to } \\
\text { pay more? }\end{array}$ \\
\hline $\begin{array}{l}\text { The environment is } \\
\text { being severely } \\
\text { damaged. }\end{array}$ & 1 & $\begin{array}{c}.470 \\
0 \\
\end{array}$ & $\begin{array}{c}.314 \\
0 \\
\end{array}$ & $\begin{array}{l}0.149 \\
0.104 \\
\end{array}$ \\
\hline $\begin{array}{l}\text { I as a consumer have a } \\
\text { bigger role in } \\
\text { protecting } \\
\text { environment. }\end{array}$ & & 1 & $\begin{array}{c}.475 \\
0\end{array}$ & $\begin{array}{l}.200 \\
0.028\end{array}$ \\
\hline $\begin{array}{l}\text { Green products are } \\
\text { better option for future } \\
\text { sustainability }\end{array}$ & & & 1 & $\begin{array}{l}.231 \\
0.011\end{array}$ \\
\hline $\begin{array}{l}\text { If green features } \\
\text { increase the price of a } \\
\text { product, are you } \\
\text { willing to pay more? }\end{array}$ & & & & 1 \\
\hline
\end{tabular}

The statements presented in the above table have their corresponding $p$ value 0 or less than 0.05 . This shows that the corresponding statements possess significant relationship and correlation between them. Therefore, this adds to the validity of presented statements towards satisfying its purpose i.e. representation for environmental belief.

Table 3: Correlation amongst factors influencing green labeling

\begin{tabular}{|c|c|c|c|}
\hline Statements & $\begin{array}{l}\text { Green labels } \\
\text { are easy to } \\
\text { recognize and } \\
\text { real }\end{array}$ & $\begin{array}{l}\text { I find green labels } \\
\text { very useful in } \\
\text { choosing a product }\end{array}$ & $\begin{array}{l}\text { Green labels influence } \\
\text { me to purchase the } \\
\text { product }\end{array}$ \\
\hline $\begin{array}{c}\text { Green labels are easy } \\
\text { to recognize }\end{array}$ & 1 & $\begin{array}{c}.550 \\
0\end{array}$ & $\begin{array}{c}.410 \\
0\end{array}$ \\
\hline $\begin{array}{l}\text { I find green labels } \\
\text { very useful in } \\
\text { choosing a product }\end{array}$ & & 1 & $\begin{array}{c}.636 \\
0\end{array}$ \\
\hline $\begin{array}{l}\text { Green labels influence } \\
\text { me to purchase the } \\
\text { product }\end{array}$ & & & 1 \\
\hline
\end{tabular}


The correlation between mentioned statements is greater than .410 and their corresponding $\mathrm{p}$ values are less than 0.05 . Therefore, these statements have significant relationships and are positively correlated.

Table 4: Correlation amongst factors influencing green branding

\begin{tabular}{|c|c|c|c|}
\hline Statements & $\begin{array}{c}\text { I find green } \\
\text { branded products } \\
\text { reliable }\end{array}$ & $\begin{array}{c}\text { Green products are } \\
\text { better than non-green } \\
\text { products }\end{array}$ & $\begin{array}{c}\text { I feel brands do not } \\
\text { truly satisfy the } \\
\text { greening process. }\end{array}$ \\
\hline $\begin{array}{c}\text { I find green branded } \\
\text { products reliable }\end{array}$ & 1 & .314 & -0.016 \\
\hline $\begin{array}{c}\text { Green products are } \\
\text { better than non-green } \\
\text { products }\end{array}$ & & 1 & 0.863 \\
\hline $\begin{array}{c}\text { I feel brands do not } \\
\text { truly satisfy the } \\
\text { greening process. }\end{array}$ & & & -0.075 \\
\hline
\end{tabular}

The statements 'I find green branded products reliable' and 'Green products are better than non-green products' is . 314 and the corresponding $p$ value is 0 , which is less than 0.05 . Therefore there is a significant relationship between the two statements. The correlation between statements 'I find green branded products reliable' and 'I feel brands do not truly satisfy the greening process' is -0.016 and the corresponding $\mathrm{p}$ value is 0.863 . The negative correlation indicates that respondents who find green products reliable also feel that brands do satisfy their greening process. The correlation between statements 'Green products are better than non-green products' and 'I feel brands do not truly satisfy the greening process' is -0.075 and the corresponding $\mathrm{p}$ value is 0.417 . The negative correlation indicates that respondents who agree that green products are better than non-green products also feel that green brands do satisfy the greening process.

The undertaken statements show to have a positive and significant correlation amongst themselves. 
Table 5: Correlation amongst factors influencing green advertising

\begin{tabular}{|c|c|c|c|}
\hline Statements & $\begin{array}{c}\text { Green } \\
\text { advertising } \\
\text { catches my } \\
\text { attention }\end{array}$ & $\begin{array}{c}\text { I enjoy watching } \\
\text { advertisement focusing } \\
\text { on product's } \\
\text { environmental values }\end{array}$ & $\begin{array}{c}\text { Attractive } \\
\text { environmental } \\
\text { advertisement will } \\
\text { encourage me to buy } \\
\text { green products }\end{array}$ \\
\hline $\begin{array}{c}\text { Green advertising } \\
\text { catches my attention }\end{array}$ & 1 & .787 & .564 \\
\hline $\begin{array}{c}\text { I enjoy watching } \\
\text { advertisement focusing } \\
\text { on product's } \\
\text { environmental values }\end{array}$ & 0 & 1 & 0 \\
\hline $\begin{array}{l}\text { Attractive } \\
\text { environmental } \\
\text { advertisement will } \\
\text { encourage me to buy } \\
\text { green products }\end{array}$ & & & .567 \\
\hline
\end{tabular}

This is shown by the positive correlation values and $p$ value being less than 0.05 . Consequently, this increases the reliability of the statements towards representing green advertising.

\section{Table 6: Correlation amongst factors influencing green packaging}

\begin{tabular}{|c|c|c|c|}
\hline Statements & $\begin{array}{c}\text { Packaging helps } \\
\text { me distinguish a } \\
\text { green product }\end{array}$ & $\begin{array}{c}\text { I find eco-friendly } \\
\text { packaging more } \\
\text { appealing than non- } \\
\text { eco-friendly packaging }\end{array}$ & $\begin{array}{c}\text { I prefer to buy } \\
\text { products that use } \\
\text { eco-friendly } \\
\text { packaging }\end{array}$ \\
\hline $\begin{array}{c}\text { Packaging helps me } \\
\text { distinguish a green } \\
\text { product }\end{array}$ & 1 & .355 & .359 \\
\hline $\begin{array}{c}\text { I find eco-friendly } \\
\text { packaging more } \\
\text { appealing than non-eco- } \\
\text { friendly packaging }\end{array}$ & 0 & 0 \\
\hline $\begin{array}{c}\text { I prefer to buy products } \\
\text { that use eco-friendly } \\
\text { packaging }\end{array}$ & 1 & 097 \\
\hline
\end{tabular}

The correlation between all statements presented in the table above to represent green packaging shows high significance and positive correlation. Therefore, statements considered to measure green packaging are in coherence towards achieving the intended result. 


\subsection{Hypothesis Testing}

One sample T-test is a statistical procedure performed for testing the mean value of a distribution. It determines whether the sample mean is statistically different from a known or hypothesized population mean. The One Sample $t$ Test is a parametric test and has been used under the assumption that the sampled distribution is normal. Testing was done on five study variables. Green marketing tools have been used as independent variable to depict its impact on consumer purchase intention. The test has been conducted using solely $\mathrm{T}$-test and neither regression nor correlation has been done.

Table 7: One Sample T-Test between green marketing tools and consumer purchase intention

\begin{tabular}{|c|c|c|c|c|c|}
\hline Environmental concerns and beliefs & Mean & $\begin{array}{c}\text { Std. } \\
\text { Deviation }\end{array}$ & $\mathbf{t}$ & Sig. & Remarks \\
\hline $\begin{array}{l}\text { The environment is being severely } \\
\text { damaged. }\end{array}$ & 1.54 & 0.709 & $\begin{array}{c}- \\
22.537\end{array}$ & 0.00 & Significant \\
\hline $\begin{array}{l}\text { I as a consumer have a bigger role in } \\
\text { protecting environment. }\end{array}$ & 1.88 & 0.822 & 14.885 & 0.00 & Significant \\
\hline $\begin{array}{l}\text { Green products are better option for } \\
\text { future sustainability }\end{array}$ & 1.67 & 0.781 & $\begin{array}{c}- \\
18.691\end{array}$ & 0.00 & Significant \\
\hline $\begin{array}{l}\text { If green features increase the price of } \\
\text { a product, are you willing to pay } \\
\text { more? }\end{array}$ & 2.33 & 0.901 & -8.103 & 0.00 & Significant \\
\hline $\begin{array}{c}\text { Green labeling and consumer } \\
\text { purchase intention }\end{array}$ & Mean & $\begin{array}{c}\text { Std. } \\
\text { Deviation }\end{array}$ & $\mathbf{t}$ & Sig. & Remarks \\
\hline Green labels are easy to recognize & 2.55 & 0.915 & -5.386 & 0.00 & Significant \\
\hline $\begin{array}{l}\text { I find green labels very useful in } \\
\text { choosing a product }\end{array}$ & 2.38 & 0.889 & -7.698 & 0.00 & Significant \\
\hline $\begin{array}{l}\text { Green labels influence me to purchase } \\
\text { the product }\end{array}$ & 2.52 & 0.961 & -5.508 & 0.00 & Significant \\
\hline $\begin{array}{c}\text { Green branding and consumer } \\
\text { purchase intention }\end{array}$ & Mean & $\begin{array}{c}\text { Std. } \\
\text { Deviation }\end{array}$ & $\mathbf{t}$ & Sig. & Remarks \\
\hline I find green branded products reliable & 2.41 & 0.794 & -8.165 & 0.00 & Significant \\
\hline $\begin{array}{l}\text { Green products are better than non- } \\
\text { green products }\end{array}$ & 2.18 & 0.809 & $\overline{-}$ & 0.00 & Significant \\
\hline $\begin{array}{l}\text { I feel brands do not truly satisfy the } \\
\text { greening process. }\end{array}$ & 2.93 & 0.881 & -0.933 & 0.353 & $\begin{array}{c}\text { Not } \\
\text { Significant } \\
\end{array}$ \\
\hline $\begin{array}{c}\text { Green advertising and green } \\
\text { purchase intention }\end{array}$ & Mean & $\begin{array}{c}\text { Std. } \\
\text { Deviation }\end{array}$ & $\mathbf{t}$ & Sig. & Remarks \\
\hline $\begin{array}{c}\text { I enjoy watching advertisement } \\
\text { focusing on product's environmental } \\
\text { values }\end{array}$ & 2 & 0.778 & 13.181 & 0.00 & Significant \\
\hline
\end{tabular}




\begin{tabular}{|c|c|c|c|c|c|}
\hline $\begin{array}{l}\text { Green advertising catches my } \\
\text { attention }\end{array}$ & 2.07 & 0.769 & 14.083 & 0.00 & Significant \\
\hline $\begin{array}{l}\text { Attractive environmental } \\
\text { advertisement will encourage me to } \\
\text { buy green products }\end{array}$ & 1.63 & $0.819 \mathrm{w}$ & $18 . \overline{2} 74$ & 0.00 & Significant \\
\hline $\begin{array}{c}\text { Green packaging and green } \\
\text { purchase intention }\end{array}$ & Mean & $\begin{array}{c}\text { Std. } \\
\text { Deviation }\end{array}$ & $t$ & Sig. & Remarks \\
\hline $\begin{array}{l}\text { Packaging helps me distinguish a } \\
\text { green product }\end{array}$ & 2.23 & 0.877 & -9.579 & 0.00 & Significant \\
\hline $\begin{array}{l}\text { I find eco-friendly packaging more } \\
\text { appealing than non-eco-friendly } \\
\text { packaging }\end{array}$ & 2.1 & 0.76 & 12.966 & 0.00 & Significant \\
\hline $\begin{array}{l}\text { I prefer to buy products that use eco- } \\
\text { friendly packaging }\end{array}$ & 2.1 & 0.726 & $\begin{array}{c}- \\
13.571\end{array}$ & 0.00 & Significant \\
\hline
\end{tabular}

The outcomes of the research was as expected, where green marketing elements i.e. environmental belief, green labeling, green branding, green advertisement and green packaging had a significant impact on purchase intention of customers

The mean of statements measuring environment concerns and beliefs with respect to the consumer purchase intention has mean values lower than 3 . This indicates that most of the respondents agree that the environment is indeed being severely damaged. The significant value ( $p$-value) for all statements is 0.00 , which is less than 0.05 , which indicates the significance of the statement.

The mean of the statement measuring green labeling with respect to the consumer purchase intention has mean values lower than 3. This indicates that most of the respondents agree that green labeling does influence consumer purchase intention. The significant value ( $\mathrm{p}$-value) for all statements is 0.00 , which is less than 0.05 , which indicates that the statement is significant.

The mean of the statement measuring green branding with respect to the consumer purchase intention has mean values lower than 3 . Hence, most of the respondents find green branded product reliable, however, most consumers believe that green brands do not truly satisfy the greening process. The significant value (p-value) for statement 1 and 2 is 0.00 , which is less than 0.05 which indicates that the statement is significant. The significant value (p-value) for statement 3 is 0.353 , which is more than 0.05 indicates that statement is not significant.

The mean of the statement measuring green advertisement and green packaging with respect to the consumer purchase intention has mean values lower than 3 . Hence, most of the respondents agree that green advertisement catches their attention. The significant value ( $p$-value) of all statements under these categories is 0.00 , which is less than 0.05 , indicates that the statement is significant. 


\subsection{Analysis of Experts Opinions}

The awareness level of consumers about green products, its benefits and positive effect in their lifestyle has been increasing. Consumers today have greater concerns for products that are environmentally safe as well as those that help to achieve a better way of life, according to Marketing Manager (Beko Electronics) ${ }^{7}$. Both Marketing Head (Asian Paints Nepal) ${ }^{8}$ and Proprietor (Jamarko) ${ }^{9}$ have similar views on the growing market of informed green consumers. Further Proprietor (Jamarko) adds that packaging helps to better communicate a product's ecofriendliness.

However, Proprietor (Jamarko) argues that people still show negligence towards green purchases. She explains that one time purchase does not make a significant impact nor does it prove someone being environmentally friendly, it needs to be enacted in everyday living. The marketing head (Asian Paints Nepal),on the other hand, stresses the need to put additional effort in marketing the benefits of green products. He believes that consumers still need to be made more aware and responsible to really influence the green purchase intention.

Furthermore, a salesperson at Kirloskar Green Generators highlighted branding was a major factor for increased believes that "green" branding has made consumers perceive

Kirloskar as a low emission (in terms of harmful gas and noise) brand. He says- "In Kathmandu where there is space constrains; portability, less noise and emission control has been a key to Kirloskar generator's success". Promotional activities conducted by brands influence consumer's perception, also affects consumer's trust towards the product.

The views given by marketing experts and the findings of the research present a similar picture on the increased awareness amongst consumers about green purchases and increasing environmental enthusiasm. It is also a relevant fact that a high price of green product has been a constraint towards its greater purchase.

The research also supports the impact and need of green branding and advertisement being useful to promote and persuade consumers towards green purchases. Environmental responsibility is an attribute that still needs to be enhanced to increase the green purchase behavior amongst consumers. However, marketing activities needs to differ depending on the product type to increase impact.

\footnotetext{
Mr. LaxmanSapkota, Marketing Manager- Beko Electronics

Mr. Shankar Banjara, Marketing Head- Asian Paints Nepal

9 Ms. Kritica Lacoul, Proprietor- Jamarko
} 


\section{Concluding Remarks}

The study focuses on the impact of green marketing tools on consumer purchase intention in Kathmandu. The key issues regarding global warming, biodegradable, recyclability or re-usability and positive health effects of green products have generated interest and intention on green purchase, and have also created a new breed of consumers known as 'green-consumers'.

An investigation on the variables indicating the significance of environmental belief shows its positive and significant impact on the purchase intention of the consumers. Eco-packaging adds an entire new dimension to green marketing; it has a significant impact on the purchase intention of consumers. Packaging assisted consumers to distinguish and differentiate a green product from a non-green product. Consumers also preferred products that used green medium of packaging to a traditional packaging material.

It was observed that eco brands were creating a positive image on the mind space of the consumers and have been able to develop trust and reliability. It appears that awareness of eco-brands amongst consumers in Kathmandu is increasing, though popularity is mostly limited to food products. The consumers are also attracted towards green values of automobiles and electronic products. Environmental advertisement is another dimension of green marketing that has a significant impact on the consumer purchase intention. It has been agreed that green advertisement catches attention of consumers and they enjoy knowing how a product builds on its environmental values. Product information on eco labels is also identified to have a significant effect on the purchase consideration. It seems consumers are now more aware of the choices they make and want to make informed decisions. Labels help them to connect to the product and know what they are exactly purchasing.

It was also found that green-marketing elements did impact purchase intention of consumers towards developing an image and building perception leading to purchase of green products. The key aspect influenced the consumer's green purchase intention was their self-felt environment protection responsibility. Similarly, price is a principle consideration before purchasing a green product, and the willingness to pay reflected only a little increment over current price, considering other substitutes.

Moreover, some respondents believed that companies used environmental issues only as a medium to boost sales, though majority of them were neutral to this issue. Similar results were also found when asked about if companies were only claiming their products to be green when actually they were not. Moreover, majority of the 
respondents agreed that they did check if the product they were buying was environmental friendly or not.

The major finding of this paper is that green-marketing tools were observed to have a significant impact on the purchase intention towards green products. Nevertheless, the feeling of environment protection also further fuels the intent for green purchase. These findings depict that the interest on green product and environment is spreading amongst the residents of Kathmandu valley, which was also agreed by the marketing experts. However, they argued that there still is a need to inform and educate consumers about unique value addition that green features bring, and the benefits associated with it. They further opined that environment friendly lifestyle is not depicted by one time purchase or association with an event, it is a continuous process which needs to be enacted upon every day.

The research reveals that price is a fundamental barrier that limits the adaption of green products. Green purchases would be an equal competitor to non-green products only if the prices of green products become lesser than the prices of nongreen products. As this would serve the long run interest of environment protection and support sustainability, government subsidy could be a medium of making green products more affordable. Such subsidy would also encourage people with less income to purchase such products. Once people become habituated with the benefits, subsidies can be perhaps withdrawn from products of private manufacturers.

\section{REFERENCES}

Aryal, K. (2008). General perceptions of producer, traders and consumers about organic products in traders and consumers about organic products in Kathmandu Valley. In P. Chaudhary; K. Aryal and D. Tharu (ed.), Proceedings of International Workshop on Opportunities and Challenges of Organic Production and Marketing in South Asia, pp. 120-124. Kathmandu.

Bhatta, G. D., Doppler, W., \& KC, K. B. (2008). Problems and potentials of organic agriculture development in Nepal. Conference on International research on food security, Natural resource management and rural development, 1-4.

Borin, N., Douglas, C., \& Krishnan, R. (2011). Consumer effects of environmental impact in product labeling. Journal of Consumer Marketing, 28(1), 76-86.

Bukhari, S. S. (2011). Green marketing and its impact on consumer behavior. European Journal of Business and Management, 3(4), 375-383. 
Cairncross, S. (2003). Water supply and sanitation: some misconceptions. Tropical Medicine and International Health, 8(3), 193-195.

Chatterjee, P. (2009). Green brand extention strategy and online communities. Journal of Systems and Information Technology, 11(4), 367-384.

Curlo, E. (1999). Marketing strategy, product safety, and ethical factors in consumer choice. Journal of Business Ethics, 21(1), 37-48.

Elham Rahbar, Nabsiah Abdul Wahid, (2011). Investigation of green marketing tools' effect on consumers' purchase behavior, Business Strategy Series, 12(2), pp. $73-83$.

Gupta, S., \& Ogden, D. (2009). To buy or not to buy? A social dilemma perspective on green buying. Journal of Consumer Marketing, 26(6), 376-91.

Handriana, D. (2016, May).Mapping of Green Buying Perception in Developing Country. Mediterranean Journal of Social Sciences, 7(3), 19-30.

Isa, S. M., \& Yao, P. X. (2013, August). Investigating the preference for green packaging in consumer product choices: A choice-based conjoint approach. Business Management Dynamics, 3(2), 84-96.

Junyi Shen (2012).Understanding the determinants of consumer's willingness to pay for eco-labeled products: An empirical analysis of China environmental label, Journal of Service Science and Management, 2012, 5, 87-94

Juwaheer, T. D., Pudaruth, S., \& Noyaux, M. M. (2012). Analysing the impact of green marketing strategies on consumer purchasing patterns in Mauritius. World Journal of Entrepreneurship,Management and Sustainable Development, 8(1), 36-59.

Lindsay Richards (2013).Examining Green Advertising and Its Impact on Consumer Skepticism and Purchasing Patterns, The Elon Journal of Undergraduate Research in Communications, 4(2).

Mourad, M., \& Ahmed, Y. S. (2012). Perception of green brand in an emerging innovative market. European Journal of Innovative Management, 15(4), 514537.

Naizi, G. S., Siddiqui, J., Shah, B. A., \& Hunjra, A. I. (2012). Effective advertising and its influence on consumer buying behavior. Information Management and Business Review, 4(3), 114-119.

Ottman, J., Stafford, E., \& Hartman, C. (2006). Avoiding green marketing myopia: ways to improve consumer appeal for environmentally preferable products. Environment, 48(5), 22-36. 
Saleem, S., \& Abideen, Z. U. (2011). Effective advertising and its influence on consumer buying behavior. European Journal of Business and Management, 3(3), 55-66.

Sapkota,S. and Phuyal,R.K.(2016). An analysis of consumers' awareness and their purchasing behavior for adulterated rice-grains in Nepal. World Review of Business Research, 6 (2), 98-119.

Whitlar, D., Geurts, M., \& Swenson, M. (1993). New product forecasting with a purchase intention survey. The Journal of Business Forecasting Methods Systems and Systems, 12(3), 1-18. 